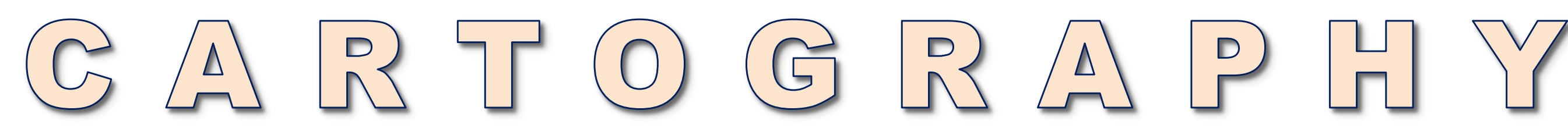 \\ art • science • engineering • technology
}

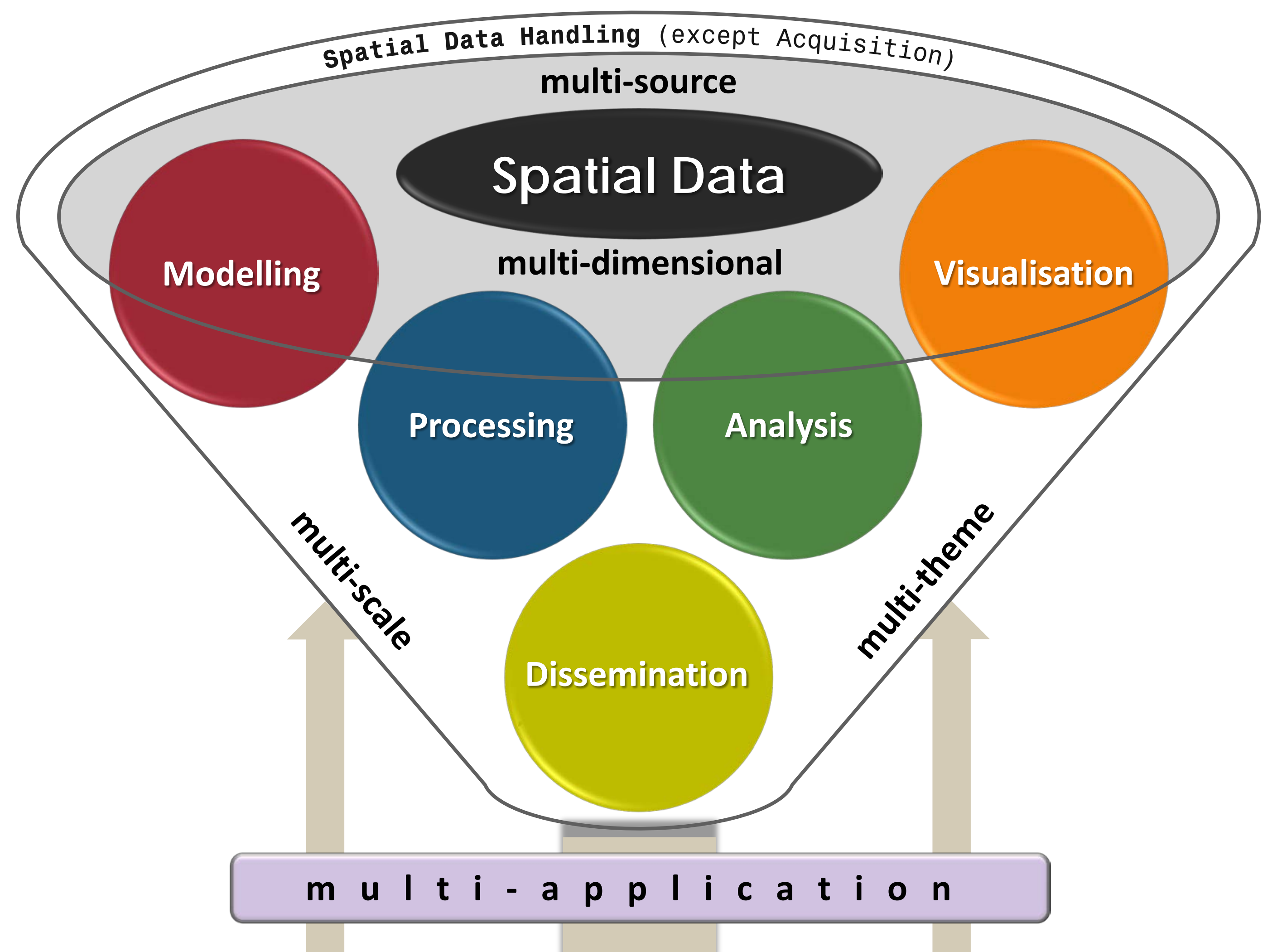

\section{Spatial Data Infrastructure}

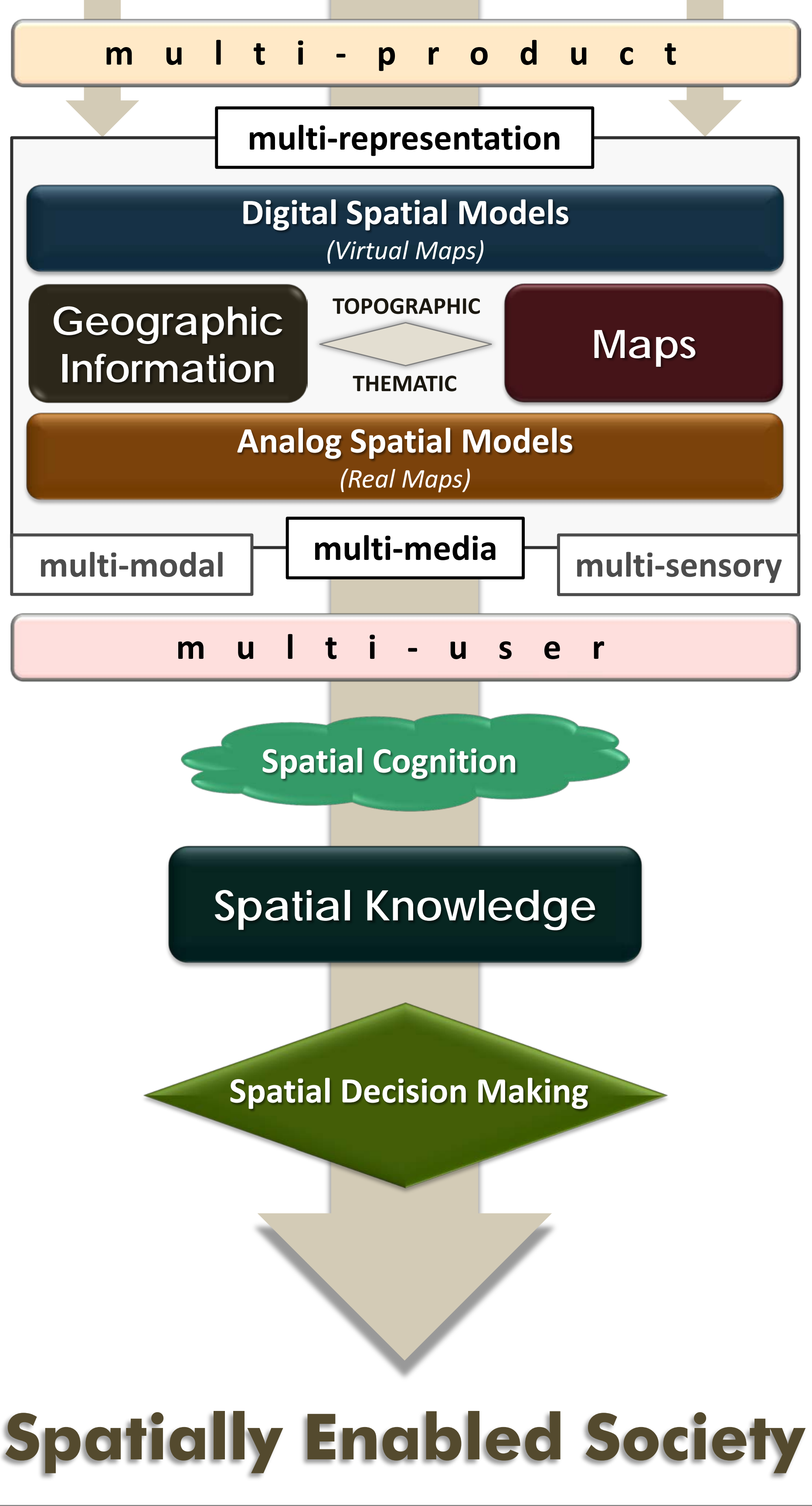

